Brazilian Journal

of Chemical

ISSN 0104-6632

Printed in Brazil

Engineering

www.scielo.br/bjce

Vol. 35, No. 03, pp. 1141-1152, July - September, 2018

dx.doi.org/10.1590/0104-6632.20180353s20170003

\title{
STUDY OF ALPHA-AMYLASE OBTAINED BY SOLID STATE FERMENTATION OF CASSAVA RESIDUE IN AQUEOUS TWO-PHASE SYSTEMS
}

\author{
Adejanildo da Silva Pereira ${ }^{1}$, Rafael Ilhéu da Costa Fontan ${ }^{1}$, Marcelo Franco ${ }^{2}$, \\ Evaldo Cardozo de Souza Júnior ${ }^{1}$, Cristiane Martins Veloso ${ }^{1}$, Vanessa Santos \\ Sampaio $^{1}$, Paulo Bonomo ${ }^{1}$ and Renata Cristina Ferreira Bonomo ${ }^{1, *}$
}

${ }^{1}$ State University of Southwest Bahia (UESB), Itapetinga-BA, Brazil.

${ }^{2}$ State University of Santa Cruz (UESC), Ilhéus-BA, Brazil.

(Submitted: January 4, 2017. Revised: September 21, 2017. Accepted: September 29, 2017)

\begin{abstract}
The $\alpha$-amylase enzyme was produced by solid state fermentation (SSF) and its partition behavior in Aqueous Two-Phase Systems (ATPS) was determined using systems consisting of polyethylene glycol (PEG) and potassium phosphate buffer. To determine the best conditions for $\alpha$-amylase production, a central composite design was constructed for two independent variables: fermentation time and moisture content, and for the partition study, a face-centered central composite design (CCF) with four independent variables: PEG molecular weight, $\mathrm{pH}$, temperature and partition time. It was indicated that the best enzyme production conditions were a fermentation time of 35.0 hours and $45.7 \%$ moisture content. From the results obtained, it was found that increasing the polymer molecular weight promotes a reduction of the enzyme concentration in the upper phase, increasing its concentration in the lower phase. It was also observed that the partition coefficients increased with increasing $\mathrm{pH}$ values and a reduction in temperature.
\end{abstract}

Keywords: Liquid-liquid extraction; Enzymes; DCCR; Fermentation; Residue.

\section{INTRODUCTION}

The production of waste and by-products is inherent in all production sectors. With the improvement of ecological awareness in the late 20th century, it became clear that the greatest challenge facing humanity in the coming decades is to balance the production of goods and services with economic growth, social equity and environmental sustainability (Galembeck et al., 2009; Pelizer et al., 2007). Thus, advances in industrial biotechnology have offered potential opportunities for economic exploitation of these wastes.
$\alpha$-Amylase (1,4- $\alpha$-D-glucan glucano hydrolase, EC 3.2.1.1) is a class of hydrolases that are widely distributed in nature. They act specifically on the glycosidic linkages of starch, especially in digestion, including salivary and pancreatic amylases, in grain germination and microbial growth (Eliasson, 2006; Whitaker, 1993). $\alpha$-amylase is considered to be one of the most important enzymes in starch, food, paper, detergents, pharmaceuticals, textiles, baking and brewing industries (Gupta et al., 2003). These enzymes randomly cleave the $\alpha-1,4$ bonds between adjacent glucose units in starch and related polysaccharides to

*Corresponding author. E-mail address: bonomorcf@pq.cnpq.br 
produce mainly maltose and maltodextrins (Singh and Kayastha, 2014).

Traditionally, these enzymes have been produced by submerged fermentation. However, in the last decade solid-state fermentation (SSF) has been increasingly studied for the production of these enzymes. SSF is a technique which consists of microorganism growth on and in moist porous particles, which must possess sufficient moisture to sustain the growth and metabolic activity of the microorganism (Thomas et al., 2013).

Optimization of the enzyme production steps, as well as their separation and purification, is of fundamental importance to increase the purity and efficiency of these products. Thus, the separation and purification of biomolecules have acquired increasing industrial importance. One technique that has shown potential for separation of biocompounds is liquid-liquid extraction using aqueous two-phase systems (ATPS). This method offers high efficiency, productivity, selectivity and a higher degree of purity, combined with technological simplicity and low cost (Pei et al., 2009; Zafarani-Moattar and Hamzehzadeh, 2010). One of the main advantages of the aqueous two-phase system (ATPS) is the aqueous environment, which provides suitable conditions for the distribution of biomolecules, such as enzymes, into phases without the occurrence of changes in their conformation and consequent loss of biological activity (de Sousa et al., 2009; Pessoa and Kilikian, 2005). The ATPS are formed by combining three or more chemical species that, in determined conditions, separate into two distinct phases whose major component is water. Traditionally, these systems are formed by polyethylene glycol (PEG), since it easily forms a two-phase system with neutral inorganic salts and polymers (Salabat, 2001).

To optimize the use of ATPSs in the partitioning of biocompounds, it is necessary to study the behavior of these systems in different compositions and varied temperature and $\mathrm{pH}$ conditions. Thus, since 1960 several studies have been conducted to determine the most appropriate ATPSs and the best conditions for partitioning and/or concentration of animal or plant cells, enzymes, proteins, nucleic acids, viruses, metals and others (Alcântara et al., 2014; de Souza Jr et al., 2014; Mageste et al., 2012).

In the present work, an optimization study was performed for production of the $\alpha$-amylase enzyme by solid state fermentation and for a partition study of this enzyme in ATPSs composed of polyethylene glycol, water and inorganic salt. To optimize the production of this enzyme by the SSF technique, both moisture content and fermentation time were varied to evaluate their effect on the response variable Specific Activity (SA). To study the partitioning of pure $\alpha$-amylase, a face-centered central composite design was used, as a function of the variation of the molecular weight of the polymer, $\mathrm{pH}$, temperature and partitioning time, where the coefficients of protein partitioning $(\mathrm{Kp})$ and enzymatic activity $(\mathrm{Ke})$ were assessed. Based on these strategies, the effects of these variables on the behavior of the production and partitioning of the enzyme were identified, as well as the establishment of mathematical models which represent the processes used, allowing the determination of the best values of the response variables in the ranges studied. The best partitioning conditions obtained for these responses were used for the separation of $\alpha$-amylase present in the crude extract produced via SSF, calculating not only the cited parameters but also selectivity (S). The parameter (S) was calculated in order to verify the efficiency of the separation process.

\section{MATERIALS AND METHODS}

\section{Materials}

Bovine serum albumin (BSA), $\alpha$-amylase, 3,5-dinitrosalicylic acid, Coomassie blue, silver nitrate, SDS, acrylamide and bis-acrylamide were purchased from Sigma Aldrich Brazil. Polyethylene glycol with molecular weights of 2000, 4000 and 6000 , monobasic and dibasic potassium phosphate, soluble starch, hydrochloric acid, phosphoric acid, acetic acid, ethanol, Tris-HCl, 2-Mercaptoethanol, glycerol, Bromophenol blue, Tween 80 and sodium potassium tartrate were purchased from Vetec, Brazil. All reagents used were of analytical grade.

\section{Solid State Fermentation}

The microorganism (fungus Aspergillus niger) was inoculated in PDA medium (Potato Dextrose Agar) and incubated at $30^{\circ} \mathrm{C}$ in a bacterial incubator (SL 222; Solab) for 7 days. The spores were extracted with a $0.01 \%$ Tween 80 solution and quantified using a Neubauer chamber and binocular microscope (L1000; Bioval).

Cassava residue was used as substrate for fungus development. Ten grams (10 g) of the previously dried residue were placed in a $125 \mathrm{~mL}$ Erlenmeyer flask and then autoclaved at $120^{\circ} \mathrm{C}$ for 15 minutes. A volume of the spore solution required to reach a concentration of $10^{7}$ spores $\cdot \mathrm{mL}^{-1}$ was inoculated (Tung et al., 2004). The inoculated residues were incubated in a bacteriological 
culture incubator at $30^{\circ} \mathrm{C}$. To determine the optimal conditions for the production of $\alpha$-amylase, a rotatable central composite design (RCCD $2^{2}$ ) was performed for the two independent variables: moisture content (MC) and fermentation time (FT), as shown in Table 1.

At the end of the respective fermentation time, 50 $\mathrm{mL}$ of sterile distilled water was added to each assay to solubilize the enzymes. This suspension remained under orbital stirring at $30^{\circ} \mathrm{C}$ for 30 minutes (QuimisQ816M20) at $200 \mathrm{rpm}$. The removal of suspended solids was carried out by mechanical pressing and the homogeneous liquid was centrifuged at $1107 \mathrm{~g}$ for 15 minutes (Centribio model $80-2 \mathrm{~B}$ ). In order to concentrate the crude enzyme extract obtained, it was dried in a lyophilizer at $-50^{\circ} \mathrm{C}$ for 48 hours, and then stored under refrigeration conditions.

\section{Determination of Enzyme Activity}

$\alpha$-Amylase activity was determined as described by Okolo et al. (1995). The reaction mixture consisted of $1.25 \mathrm{~mL}$ of $1 \%$ soluble starch, $0.25 \mathrm{~mL}$ of $0.1 \mathrm{~mol} \cdot \mathrm{L}^{-1}$ acetate buffer ( $\mathrm{pH} 5.0), 0.25 \mathrm{~mL}$ of distilled water and $0.25 \mathrm{~mL}$ of the samples. After 10 minutes of incubation at $50^{\circ} \mathrm{C}$, the released reducing sugars were estimated by the dinitrosalicylic acid method (DNS) according to Miller (1959). After reaction, the samples were read at $575 \mathrm{~nm}$ using a UV-Vis spectrophotometer (Biochrom, model 570 Libra). The blank contained $0.5 \mathrm{~mL}$ of $0.1 \mathrm{~mol} \cdot \mathrm{L}^{-1}$ acetate buffer ( $\mathrm{pH} 5.0$ ), $1.25 \mathrm{~mL}$ of a $1 \%$ starch solution and $0.25 \mathrm{~mL}$ of distilled water. According to Ghose (1987), one enzyme activity unit releases $1 \mu \mathrm{mol}$ of reducing sugar per $\mathrm{mL}$ of extract per minute. The enzyme activity (U) was calculated from Equation 1, which is expressed in $\mathrm{U} \cdot \mathrm{mL}^{-1}$.

$$
\boldsymbol{U}=T R S \times \frac{V_{T}}{0.18 \times V_{S} \times T_{H}}
$$

where TRS is the total reducing sugars produced in the hydrolysis step $\left(\mathrm{mg} \cdot \mathrm{mL}^{-1}\right)$; VT is the total volume used in the hydrolysis $(\mathrm{mL})$; $\mathrm{VC}$ is the sample volume used in the hydrolysis $(\mathrm{mL})$; TH is the hydrolysis time (min); and $0.18 \mathrm{mg} / \mu \mathrm{mol}$ of glucose.

\section{Determination of Total Proteins}

Table 1. Levels and variables analyzed in the (DCCR $2^{2}$ ) for evaluating the optimal moisture content and fermentation time for $\alpha$-amylase production.

\begin{tabular}{lccccc}
\hline \multirow{2}{*}{ Variables } & \multicolumn{5}{c}{ Levels } \\
\cline { 2 - 6 } & $\mathbf{- 1 . 4 1 4}$ & $\mathbf{- 1}$ & $\mathbf{0}$ & $\mathbf{1}$ & $\mathbf{1 . 4 1 4}$ \\
\hline FT (hours) & 10.5 & 18 & 36 & 54 & 61.5 \\
Moisture content (\%) & 34.3 & 38 & 47 & 56 & 59.7 \\
\hline
\end{tabular}

The concentration of total proteins in the enzyme extract was estimated by spectrophotometry using the method based on adsorption of the reagent Coomassie Brilliant Blue G-250 as proposed by Marion Bradford (1976). Initially, $100 \mathrm{mg}$ of this reagent were weighed on aluminum foil and then diluted in $50 \mathrm{~mL}$ of $95 \%$ ethanol (v/v) with vigorous stirring. Next, $100 \mathrm{~mL}$ of $85 \%$ phosphoric acid $(\mathrm{w} / \mathrm{v})$ were diluted in $1 \mathrm{~L}$ of distilled and deionized water in a volumetric flask. It was filtered under vacuum in a Millipore system with Whatman $\mathrm{n}^{\circ} 113$ filter paper to remove insoluble components. There was visual evidence of a color change from blue to brown. The solution was then placed in a glass bottle covered with aluminum foil to protect the Bradford reagent from photodegradation. Stability was ensured by storage at $4^{\circ} \mathrm{C}$. The calibration curve was constructed using the protein Bovine Serum Albumin (BSA) as the standard, with readings performed at the wavelength of $595 \mathrm{~nm}$.

\section{Specific Activity}

The specific activity of $\alpha$-amylase in the crude extract was determined by the ratio between the enzyme activity $\left(\mathrm{U} \cdot \mathrm{mL}^{-1}\right)$ and the total protein concentration $\left(\mathrm{mg} \cdot \mathrm{mL}^{-1}\right)$, as shown in Equation 2:

$$
\mathbf{S A}=\frac{\text { Activity of } \alpha-\text { amylase }}{\text { Concentration of proteins }}
$$

The extract which presented the highest specific activity (SA) among the treatments studied was used in SDS-PAGE electrophoresis. This procedure was performed in order to confirm the presence of $\alpha$-amylase in the crude enzyme extract. For this analysis an acrylamide gel was prepared with a separating gel at $12 \%$ and a $5 \%$ stacking gel. Aliquots of the preconcentrated enzyme extract were resuspended in denaturing buffer (Tris- $\mathrm{HCl} \mathrm{pH} 6.8,4 \%(\mathrm{w} / \mathrm{v}) \mathrm{SDS}$, $4 \%(\mathrm{v} / \mathrm{v})$ 2-mercaptoethanol, 20\% (v/v) glycerol and Bromophenol blue). Electrophoresis was carried out at $250 \mathrm{~V}$ and $30 \mathrm{~mA}$ for 1 hour and 30 minutes. The gel was then stained with a $0.1 \%$ silver nitrate solution (w/v) for 30 minutes in the absence of light. After this step, the revealing solution was added to the gels until the appearance of the bands.

\section{Experiments with Aqueous Two-Phase Systems}

The compositions of the systems (Table 2) formed from polyethylene glycol 4000 and $6000\left(\mathrm{~g} \cdot \mathrm{mol}^{-1}\right)$ and potassium phosphate salts were obtained from the literature (Padilha et al., 2011) and systems formed from polyethylene glycol $2000\left(\mathrm{~g} \cdot \mathrm{mol}^{-1}\right)$ and potassium 
Table 2. Overall composition of the aqueous two-phase systems used for extraction of $\alpha$-amylase, considering the final concentrations of PEG and potassium phosphate salt.

\begin{tabular}{lcc}
\hline \multirow{2}{*}{ System } & \multicolumn{2}{c}{ Total composition } \\
\cline { 2 - 3 } & PEG (w/w) & SALT (w/w) \\
\hline PEG2000-pH6 & 17.5 & 12.7 \\
PEG2000-pH7 & 19.1 & 12.5 \\
PEG2000-pH8 & 17.7 & 12.0 \\
PEG4000-pH6 & 16.7 & 13.3 \\
PEG4000-pH7 & 16.2 & 13.5 \\
PEG4000-pH8 & 19.5 & 11.0 \\
PEG6000-pH6 & 19.0 & 12.3 \\
PEG6000-pH7 & 21.0 & 11.6 \\
PEG6000-pH8 & 23.7 & 10.5 \\
\hline
\end{tabular}

phosphate salts were determined in this work. The stock solutions of polyethylene glycol $(50 \% \mathrm{w} / \mathrm{w})$ and potassium phosphate buffer $(20 \% \mathrm{w} / \mathrm{w})$ were prepared before conducting the experiments. The $\mathrm{pH}$ of the PEG solution was adjusted to $(6,7$ and 8$)$ by the addition of phosphoric acid and potassium hydroxide, and that of the potassium phosphate buffer solution using dibasic and monobasic potassium phosphate in the ratio of 1: $1.82(\mathrm{w} / \mathrm{w})$. To prepare the ATPSs with 45 $\mathrm{g}$, the corresponding amounts of PEG and phosphate buffer were mixed and then incubated for 12 hours to allow for phase separation. The phases of the preequilibrated ATPSs were collected with the aid of 20 $\mathrm{mL}$ syringes and used in the formation of new systems of equal volume. This procedure was carried out so as to obtain an upper phase volume / lower phase volume relationship equal to one. The partition experiments were carried out in graduated centrifuge tubes to which $2.5 \mathrm{~mL}$ of each of the upper and lower phases of the pre-equilibrated ATPSs were added, along with $300 \mu \mathrm{g}$ of pure enzyme; these were then mixed in a vortex mixer for 2 minutes and centrifuged at $1400 \mathrm{~g}$ for $10 \mathrm{~min}$. The tubes were placed in a BOD incubator and the experiment was conducted for different times and at different temperatures. The same procedure was performed for $\alpha$-amylase partition in the enzyme extract with the greatest specific activity.

\section{Assays of $\alpha$-Amylase Partitioning}

A face-centered central composite design (CCF) was performed in order to characterize the effects of polymer molecular weight $\left(x_{1-} \mathrm{MM}_{\mathrm{peg}}\right), \mathrm{pH}$ $\left(x_{2}\right)$, temperature $\left(x_{3}-\mathrm{T}\left({ }^{\circ} \mathrm{C}\right)\right)$ and partition time ( $x_{4-}$ tp (hours)) on pure $\alpha$-amylase partitioning. Table 3 shows the coded and uncoded values of each factor. The response variables studied were the partition coefficients of enzyme activity $(\mathrm{Ke})$ and proteins $(\mathrm{Kp})$,
Table 3. Coded and uncoded values of the variables studied in the facecentered central composite design.

\begin{tabular}{lccc}
\hline Factor & Low level (-1) & $\begin{array}{c}\text { Central point } \\
(\mathbf{0})\end{array}$ & High level (+1) \\
\hline$x_{1} \mathrm{MMPEG}$ & 2000 & 4000 & 6000 \\
$x_{2} \mathrm{pH}$ & 6 & 7 & 8 \\
$x_{3} \mathrm{~T}\left({ }^{\circ} \mathrm{C}\right)$ & 5 & 15 & 25 \\
$x_{4} \mathrm{tP}(\mathrm{h})$ & 6 & 12 & 18 \\
\hline
\end{tabular}

and selectivity (S). The combinations that showed the best values of the response variables ( $\mathrm{Ke}$ and $\mathrm{Kp}$ ) for partitioning of pure $\alpha$-amylase were used as a reference, and therefore used in partitioning of the enzyme extract produced by solid state fermentation. For these combinations selectivity was calculated as well, in order to verify the efficiency of the separation process.

\section{Determination of the Partition Parameters}

To estimate protein concentrations in each phase, samples from both the top and bottom phases were collected using a syringe. Estimates were carried out by spectrophotometry, based on the adsorption of the reagent Coomassie brilliant blue G-250.

The partition coefficient was used to quantify the degree of separation achieved in extraction. The partition coefficient for enzyme activity (Ke) was defined as the enzymatic activity (U) in the upper $\left(\mathrm{A}_{\text {upp }}\right)$ and lower phases $\left(\mathrm{A}_{\text {low }}\right)$ of the system as shown in Eq. 3.

$$
\mathrm{Ke}=\frac{[\mathrm{A}]_{\mathrm{sup}}}{[\mathrm{A}]_{\mathrm{inf}}}
$$

The protein partition coefficient $(\mathrm{Kp})$, which is the relationship between the equilibrium concentration $(\mathrm{mg} / \mathrm{mL})$ of total protein in the upper $\left(\mathrm{C}_{\text {upp }}\right)$ and lower phases $\left(\mathrm{C}_{\text {low }}\right)$, was determined as described in Equation 4.

$$
\mathrm{Kp}=\frac{[\mathrm{C}]_{\text {upp }}}{[\mathrm{C}]_{\text {low }}}
$$

Selectivity (S) was calculated as the ratio between the partition coefficient of $\alpha$-amylase $\left(\mathrm{K}_{\mathrm{e}}\right)$ and the partition coefficient of the total protein $\left(\mathrm{K}_{\mathrm{p}}\right)$ (Equation 5).

$$
\mathrm{S}=\frac{\left[\mathrm{K}_{\mathrm{e}}\right]}{\left[\mathrm{K}_{\mathrm{p}}\right]}
$$

\section{Statistical Analyses}

The experimental data were subjected to analysis of variance (ANOVA), regression analysis and plotting of 
the response surface to obtain the optimum conditions for the production and partition of $\alpha$-amylase. Initially, the experimental data obtained were submitted to ANOVA and the effects were considered significant at $\mathrm{p}<0.05$. A second-order polynomial model (Equation 6) was adjusted to the experimental data and the regression coefficients were obtained by multiple linear regression.

$$
\mathbf{A E}, \mathbf{K} \mathbf{p}, \mathbf{K e}=\beta_{0}+\sum \beta_{\mathrm{i}} \mathrm{X}_{\mathrm{i}}+\sum \beta_{\mathrm{ii}} \mathrm{X}_{\mathrm{i}}^{2}+\sum \sum \beta_{\mathrm{ij}} \mathrm{X}_{\mathrm{i}} \mathrm{X}_{\mathrm{j}}
$$

where $\beta_{0}, \beta_{\mathrm{i}}, \beta_{\mathrm{ii}}$ and $\beta_{\mathrm{ij}}$ are the regression coefficients for the intercept and the linear, quadratic and interaction effects, respectively, and $X_{\mathrm{i}}$ and $\mathrm{X}_{\mathrm{j}}$ are the encoded factors. All analyses were performed using the statistical software Statistica version 8.0.

\section{RESULTS AND DISCUSSION}

\section{Solid State Fermentation}

Table 4 shows the results obtained for the specific activity (SA) of $\alpha$-amylase for the proposed experimental design. The results obtained from the statistical analysis (Analysis of variance (ANOVA) for the models) and regarding the specific activity of $\alpha$-amylase present in the crude enzyme extract acquired from SSF showed that the treatments applied were significant $(p<0.05)$ (Table 5). Equation 7 presents the mathematical model in terms of uncoded values, proposed to explain the behavior of this response in the studied range.

$$
\begin{aligned}
\mathrm{SA}= & -12.46127+0.60009 \mathrm{U}-0.00655 \mathrm{~T} \\
& +0.27361 \mathrm{U}^{2}-0.00388 \mathrm{~T}^{2}
\end{aligned}
$$

\begin{tabular}{|c|c|c|c|c|c|}
\hline \multirow[b]{2}{*}{ Assay } & \multicolumn{2}{|c|}{ Real Variables } & \multirow{2}{*}{$\begin{array}{c}\text { Activity } \\
\mathbf{U} / \mathbf{m L}\end{array}$} & \multirow{2}{*}{$\begin{array}{l}\text { Protein } \\
\mathrm{mg} / \mathrm{mL}\end{array}$} & \multirow{2}{*}{$\begin{array}{c}\text { SA } \\
(\mathbf{U} / \mathbf{m g})\end{array}$} \\
\hline & $\begin{array}{c}\begin{array}{c}\text { Time } \\
\text { (hours) }\end{array} \\
\end{array}$ & $\begin{array}{c}\text { Moisture } \\
\text { (\%) }\end{array}$ & & & \\
\hline 1 & 18 & 38 & 0.821 & 0.178 & 4.618 \\
\hline 2 & 18 & 56 & 0.832 & 0.215 & 3.872 \\
\hline 3 & 54 & 38 & 0.780 & 0.198 & 3.939 \\
\hline 4 & 54 & 56 & 0.693 & 0.203 & 3.420 \\
\hline 5 & 10.5 & 47 & 0.842 & 0.216 & 3.892 \\
\hline 6 & 61.5 & 47 & 0.752 & 0.204 & 3.684 \\
\hline 7 & 36 & 34.3 & 0.961 & 0.178 & 5.401 \\
\hline 8 & 36 & 59.7 & 0.988 & 0.193 & 5.115 \\
\hline 9 & 36 & 47 & 1.135 & 0.176 & 6.436 \\
\hline 10 & 36 & 47 & 1.079 & 0.179 & 6.015 \\
\hline 11 & 36 & 47 & 1.096 & 0.187 & 5.860 \\
\hline
\end{tabular}

From the model a surface graph was plotted for better visualization of the obtained responses (Figure 1).

It was observed that the independent variables of fermentation time and moisture content influenced the production of $\alpha$-amylase. Figure 1 shows their combined effect on the specific activity of the enzyme. From the derivative of Equation 7, it can be seen that the optimal point for SA was a time of $35 \mathrm{~h}$ and a moisture content of $47.7 \%$. This optimal point was used to obtain the crude enzyme extract used in the electrophoresis analysis and the partition experiments.

Santos et al. (2012) studied the production of cellulolytic enzymes from potato peel and noted that the production of enzymes is slow at the beginning and then accelerates to reach its maximum value; then the concentration of products generated is inhibited and its activity is reduced, which was also observed in this study.

The literature has reported the production of $\alpha$-amylase in different organisms and different substrates. Francis et al. (2003), aiming at the optimization of three parameters (incubation temperature, humidity of the substrate and the volume of the inoculum) for the production of $\alpha$-amylase by Aspergillus oryzae NRRL6270, found that the incubation temperature of $30^{\circ} \mathrm{C}$, initial moisture content of $70 \%$ and an inoculum rate of $1 \times 10^{7}$ spore. $\mathrm{g}$ of substrate were the best conditions for producing the enzyme.

Kunamneni et al. (2005) studied the production of extracellular amylase by the thermophilic fungus Thermomyces lanuginosus in different solid substrates, such as wheat bran, molasses bran, rice bran, corn flour, wheat flakes, barley meal, ground corn, corn cob and ground wheat, for the production of enzymes, and found that the fermentation of wheat bran showed the highest activity of amylase.

The protein profile for the crude enzyme extract obtained in SDS-PAGE electrophoresis is shown in Figure 2. This analysis was performed in order to confirm the presence of $\alpha$-amylase in this extract and also estimate its molar mass.

It was found that the crude enzyme extract obtained from SSF presented several bands with molecular weights ranging from roughly $21.5 \mathrm{kDa}$ to more than $116.5 \mathrm{kDa}$. The bands of the molecular markers used ranged from 6.5 to $200 \mathrm{kDa}$. The presence of a more isolated protein band can also be observed in the range of 45 to $66.2 \mathrm{kDa}$, indicating the enzyme under study. Other bands in the ranges of 66.2-97.4 kDa and 116.2-200 kDa were also observed. Dey and Banerjee 
Table 5. Analysis of variance (ANOVA) of the regression equation of $\alpha$-amylase specific activity.

\begin{tabular}{lccccc}
\hline Source & Degreeof freedom & Sum of squares & Meansquare & F-value & p-value \\
\hline Model & 4 & 9.376 & 2.344 & 19.87 & 0.0013 \\
Residue & 6 & 0.708 & 0.118 & & 0.929 \\
Lack of fit & 4 & 0.509 & 0.127 & 1.43 & 0.450 \\
Pure error & 2 & 0.178 & 0.089 & & \\
Total & 10 & 10.084 & & & \\
\hline
\end{tabular}

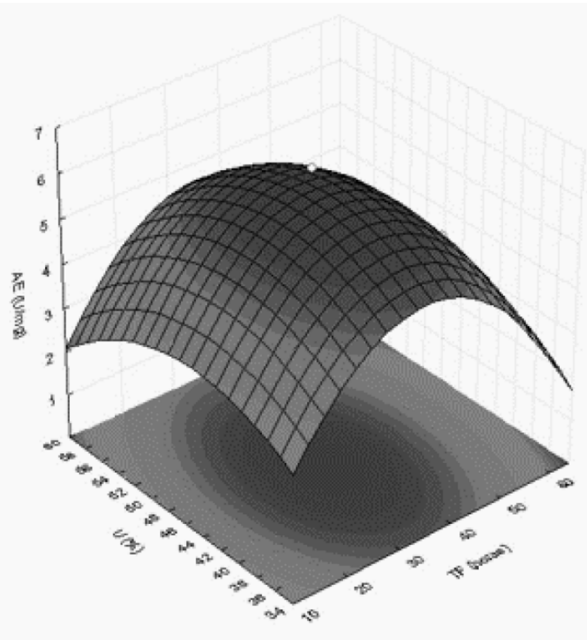

Figure 1. Response surface for the specific activity of $\alpha$-amylase as a function of humidity (U) and fermentation time (TF).

(2015), studying the purification and biochemical characterization of the $\alpha$-amylase enzyme produced by Aspergillus oryzae IFO30103, observed that the molecular weight of this enzyme was $51.3 \mathrm{kDa}$.

\section{Assays of $\alpha$-Amylase Partitioning}

Table 6 shows the experimental values for the protein partition coefficient $(\mathrm{Kp})$ and enzymatic activity (Ke) obtained in the face-centered central composite design.

The results obtained were submitted to analyses of variance of regression (Table 7). The analysis of variance (ANOVA) for the models was performed and the models' significance was examined using Fisher's statistical test (F-test) applied to significant differences between sources of variation in the experimental results, i.e., the significance of the model, the lack of fit, and the coefficient of multiple determination $\left(\mathrm{R}^{2}\right)$. The $\mathrm{p}$-value for the model indicated a high significance for the regression model. The $\mathrm{R}^{2}$ values obtained suggested a good adjustment for the model to the experimental data. So this suggested that the models were suitable for the representation of the relationship between the dependent variables ( $\mathrm{Kp}$ and $\mathrm{Ke}$ ) and independent variables (temperature, PEG

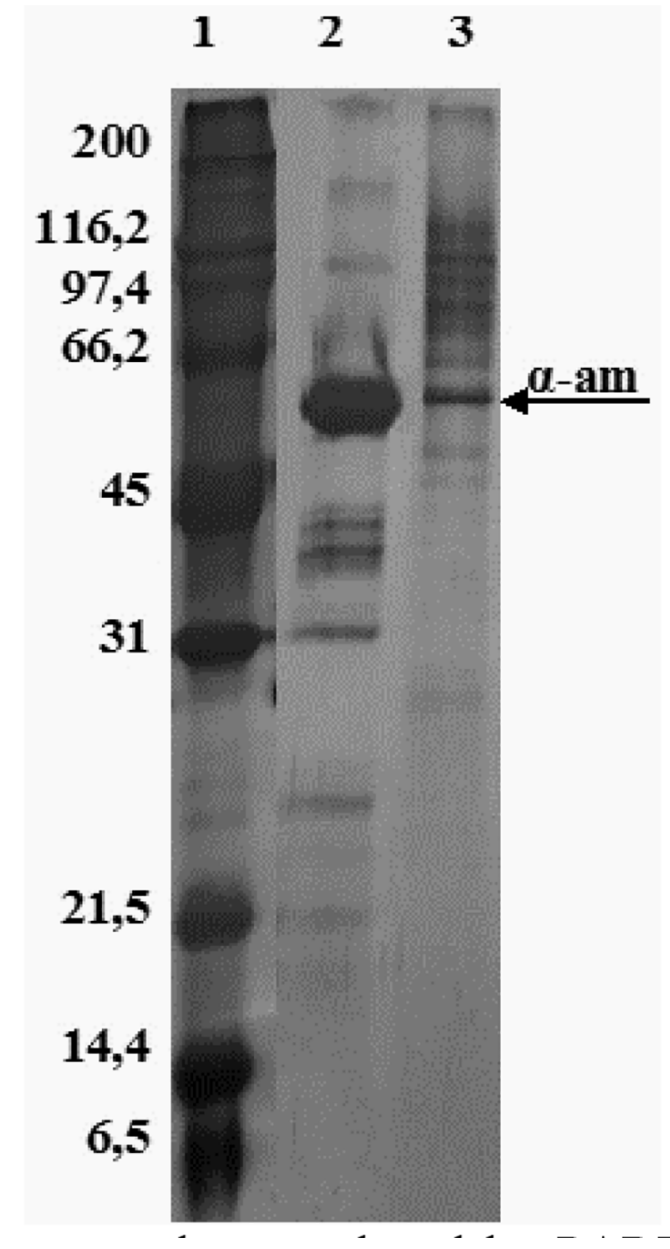

Figure 2. SDS-PAGE for the $\alpha$-amylase produced by PARTY. Well1: molecular marker proteins; 2 : Standard $\alpha$-amylase pure (>95\%) 3: Crude enzyme extract

molar mass and $\mathrm{pH}$ ). The results of the significance of the parameters analysis can be visualized in the Pareto chart (Figure 3), wherein the absolute amplitude value of the estimated standardized effect of each factor is discussed and compared with the minimum magnitude of a statistically significant factor with $95 \%$ confidence $(p=0.05)$, represented by the vertical line drawn on the graph.

From the data presented in the Pareto chart it is possible to visualize the principal effect and significant interactions on the response variables $K p$ and $K e$. It was found that the factors of the molecular weight of the polymer (linear and quadratic), $\mathrm{pH}$ (linear effect) 
Table 6. Protein partition coefficient $(\mathrm{Kp})$ and enzyme activity (Ke) for the experiments performed in the CCF.

\begin{tabular}{|c|c|c|c|c|c|c|}
\hline \multirow{2}{*}{ Assay } & \multicolumn{4}{|c|}{ Real values } & \multirow{2}{*}{$K p$} & \multirow{2}{*}{ Ke } \\
\hline & PEG[9] & pH & $\mathbf{T}\left({ }^{\circ} \mathbf{C}\right)$ & TP (hours) & & \\
\hline 1 & 2000 & 6 & 5 & 6 & 1.070 & 1.455 \\
\hline 2 & 2000 & 6 & 5 & 18 & 2.097 & 1.997 \\
\hline 3 & 2000 & 6 & 25 & 6 & 1.075 & 1.558 \\
\hline 4 & 2000 & 6 & 25 & 18 & 0.984 & 1.650 \\
\hline 5 & 2000 & 8 & 5 & 6 & 4.000 & 4.028 \\
\hline 6 & 2000 & 8 & 5 & s18 & 4.769 & 5.982 \\
\hline 7 & 2000 & 8 & 25 & 6 & 1.496 & 3.497 \\
\hline 8 & 2000 & 8 & 25 & 18 & 3.429 & 3.898 \\
\hline 9 & 6000 & 6 & 5 & 6 & 0.312 & 0.338 \\
\hline 10 & 6000 & 6 & 5 & 18 & 0.433 & 0.522 \\
\hline 11 & 6000 & 6 & 25 & 6 & 0.108 & 0.190 \\
\hline 12 & 6000 & 6 & 25 & 18 & 0.374 & 0.302 \\
\hline 13 & 6000 & 8 & 5 & 6 & 0.227 & 0.709 \\
\hline 14 & 6000 & 8 & 5 & 18 & 0.367 & 1.073 \\
\hline 15 & 6000 & 8 & 25 & 6 & 0.383 & 0.589 \\
\hline 16 & 6000 & 8 & 25 & 18 & 0.800 & 0.749 \\
\hline 17 & 2000 & 7 & 15 & 12 & 3.879 & 3.140 \\
\hline 18 & 6000 & 7 & 15 & 12 & 0.298 & 0.606 \\
\hline 19 & 4000 & 6 & 15 & 12 & 0.638 & 0.778 \\
\hline 20 & 4000 & 8 & 15 & 12 & 0.545 & 0.822 \\
\hline 21 & 4000 & 7 & 5 & 12 & 0.264 & 0.643 \\
\hline 22 & 4000 & 7 & 25 & 12 & 0.500 & 0.525 \\
\hline 23 & 4000 & 7 & 15 & 6 & 0.327 & 0.588 \\
\hline 24 & 4000 & 7 & 15 & 18 & 0.437 & 0.830 \\
\hline 25 & 4000 & 7 & 15 & 12 & 0.488 & 0.612 \\
\hline 26 & 4000 & 7 & 15 & 12 & 0.443 & 0.631 \\
\hline 27 & 4000 & 7 & 15 & 12 & 0.478 & 0.617 \\
\hline 28 & 4000 & 7 & 15 & 12 & 0.477 & 0.582 \\
\hline
\end{tabular}

Table 7. Analysis of variance (ANOVA) of of regression equations for $\mathrm{Kp}$ and $\mathrm{Ke}$ of $\alpha$-amylase values in $\mathrm{SAB}$.

\begin{tabular}{|c|c|c|c|c|c|c|}
\hline Source & DF & Sum of squares & Meansquare & F-value & p-value & $\mathbf{R}^{2}$ \\
\hline \multicolumn{7}{|l|}{ Kp } \\
\hline Model & 6 & 38.6176 & 6.4363 & 19.51 & $<0001$ & 0.8479 \\
\hline Residue & 21 & 6.9276 & 0.3298 & & & \\
\hline Lack of fit & 18 & 6.9262 & 0.3848 & 780.99 & & \\
\hline Pure error & 3 & 0.0015 & 0.0005 & & & \\
\hline Total & 27 & 45.5453 & & & & \\
\hline \multicolumn{7}{|l|}{ Ke } \\
\hline Model & 6 & 50.9222 & 8.4870 & 51.07 & $<0001$ & 0.9359 \\
\hline Residue & 21 & 3.4896 & 0.1662 & & & \\
\hline Lack of fit & 18 & 3.4883 & 0.1938 & 446.39 & & \\
\hline Pure error & 3 & 0.0013 & 0.0004 & & & \\
\hline Total & 27 & 54.4119 & & & & \\
\hline
\end{tabular}

and the interaction between the molecular weight and $\mathrm{pH}$ were statistically significant for both responses studied. It was also observed that, for the variables of temperature and partition time, only the response of $\mathrm{Ke}$ was statistically significant. It was also noted that there was an interaction between the molecular weight of the polymer and temperature for the response variable $K p$. The other terms studied were not significant at $\mathrm{p}>0.05$. 


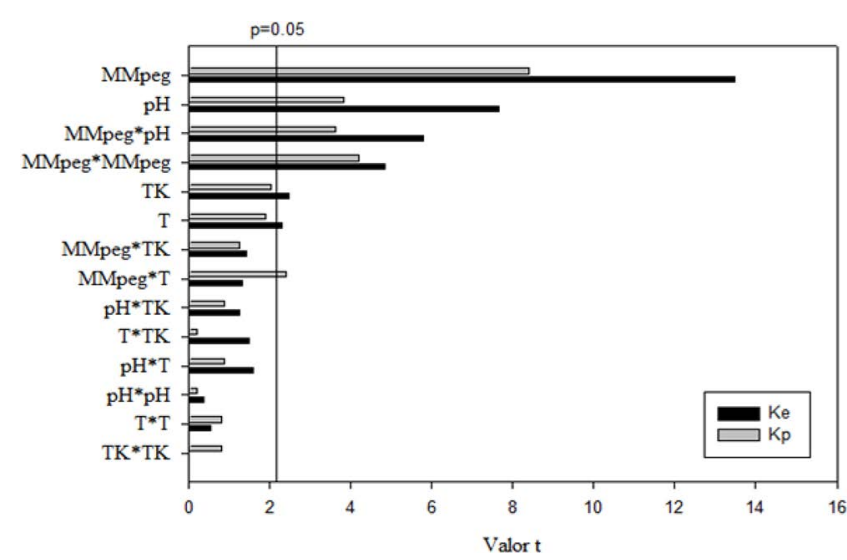

Figure 3. Pareto chart showing the significance of varying the PEG molecular weight (MMpeg), $\mathrm{pH}(\mathrm{pH})$, temperature $(\mathrm{T})$ and partition time (TK) and Ke for the variables Kp

Equations 8 and 9 present the mathematical model with the real variables, proposed to represent the partition coefficient of the protein and amylase activity for the conditions studied.

$$
\begin{aligned}
\boldsymbol{K} \boldsymbol{P}= & -2.4456-0.0010 \mathrm{MM}_{\mathrm{PEG}}+1.4854 \mathrm{pH} \\
& -0.0904 \mathrm{~T}-0.00021 \mathrm{MM}_{\mathrm{PEG}} * \mathrm{pH} \\
& +0.00002 \mathrm{MM}_{P E G} * \mathrm{~T}+2.4836 E \\
& -7 \mathrm{MM}_{\mathrm{PEG}}^{2}
\end{aligned}
$$

$$
\begin{aligned}
\boldsymbol{K} \boldsymbol{e}= & -5.2269-0.0009 \mathrm{MM}_{\mathrm{PEG}}+1.8196 \mathrm{pH} \\
& -0, .02105 \mathrm{~T}-0.0375 \mathrm{TK} \\
& -0.0003 \mathrm{MM}_{\mathrm{PEG}} * \mathrm{pH} \\
& +2.8271 \mathrm{MM}_{\mathrm{PEG}}{ }^{2}
\end{aligned}
$$

From these models, response surface graphs were plotted for better visualization of the obtained responses. Figures $4(\mathrm{a}, \mathrm{b})$ and $5(\mathrm{a}, \mathrm{b})$ illustrate the combined effects of the independent variables on $\mathrm{Ke}$ and $K p$.

The partitioning behavior of the solutes in the ATPSs must be understood in the light of the intermolecular interactions that occur during the transfer between phases. These interactions are dependent on the polymer structure, salt and polymer concentrations, and hydration of the polymer chains and ions. Moreover, the interactions of all components of the ASTPs with the partitioning solute also determine the transfer behavior. These interactions are expressed in the thermodynamic parameter denominated the standard Gibbs free energy $\left(\Delta \mathrm{G}^{\circ}\right)$, which is a function of two variables: enthalpy $\Delta \mathrm{H}^{\circ}$ and entropy $\Delta \mathrm{S}^{\circ}$, known as the Gibbs-Helmholtz relationship (de Sousa et al., 2009). Because the partitioning of biomolecules is governed by the sum of these contributions, when one exceeds the other, it governs the partition mechanism.

Figure $4 \mathrm{a}$ shows the response surface for $K p$ as a function of the polymer molecular weight and $\mathrm{pH}$. The results show that $\alpha$-amylase has a strong tendency to transfer to the polymer-rich phase when it has low molecular weight. It is believed that this flow is governed by aspects of an enthalpic nature, which may be due to a direct interaction between the protein and the PEG molecule. However, it was also observed that the enthalpic effect on partitioning decreases with increasing polymer chain length, because this increase in the degree of polymerization reduces the configurational entropy of the polymer-rich phase, so reducing the protein transfer entropy to this phase, i.e., there is an increase in the entropy difference between the system phases and its effect on partitioning prevails. Albertsson (1987) reported that an increase in the polyethylene glycol chain length reduces the degree of freedom of the molecule by decreasing the

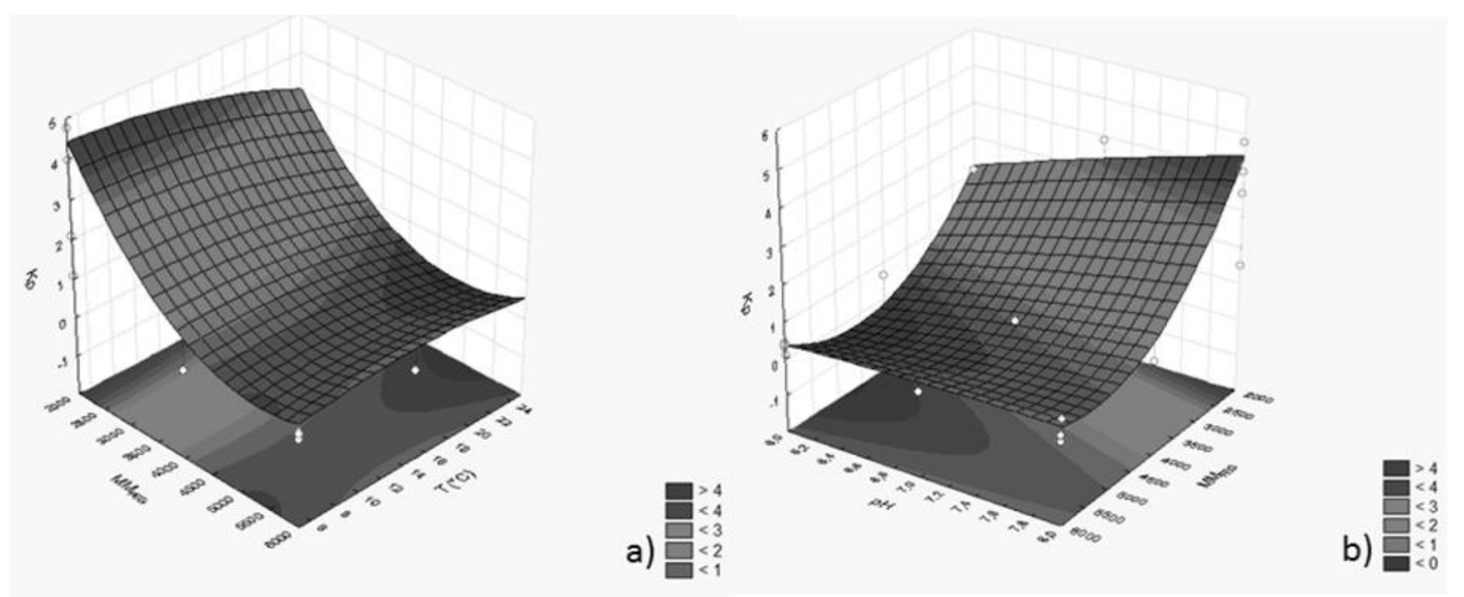

Figure 4. Response surface for the protein partition coefficient $(\mathrm{Kp})$ as a function of the molar mass of the polymer: a) (MMpeg) and $\mathrm{pH} ; \mathrm{b})(\mathrm{MMpeg})$ and temperature $\left(\mathrm{T}^{\circ} \mathrm{C}\right)$. 
configurational entropy of the system, and this increase promotes folding of the macromolecule, increasing the conformational entropy. This folding process results in a decrease in the number of sites available for interaction, which contributes to saturation of the polymer chain with a lower quantity than the other component.

Rodríguez-Durán et al. (2013) also found that with increasing PEG molecular weight there was a reduction in the partition coefficient of the tannase enzyme produced by Aspergillus niger.

Regarding the influence of $\mathrm{pH}$, it was found that the partition coefficient increased with an increase in $\mathrm{pH}$. According to de Sousa et al. (2009), the hydrogen ion concentration affects the transfer of proteins, because these biopolymers contain a wide variety of acidic and basic groups with different $\mathrm{pK}_{\mathrm{a}}$ values, resulting in electric charges which are functions of the $\mathrm{pH}$ values. These authors also indicated that the electric charge density on the protein surface can change its conformation, and association or dissociation processes among macromolecules present in the system can alter the partition behavior. Porto et al. (2011) observed that the $\mathrm{pH}$ had a statistically significant effect on the partition coefficient of lecithin.

Figure $4 \mathrm{~b}$ shows the effect of the polymer molecular weight and temperature on the $K p$. It was noted that the partition coefficient of the protein increases with decreasing temperature. When supplying energy in the form of heat, the internal energy rises, increasing the average kinetic energy of the molecules, so that they become freer to move in the solution and change the conformational entropy of the system. However, the conformational entropy of the polymer is also changed, since increasing temperature causes the folding of its chain, decreasing the number of active sites available for interaction. The reduction of these active sites promotes an increased entropy difference between the two phases of the system, and the entropic contribution becomes more pronounced, thus reducing the $K p$. Saravanan et al. (2008) studied the separation of the proteins ovalbumin and myoglobin in systems formed by PEG and polyacrylic acid, and also observed that temperature increases have a significant effect on the partitioning of these proteins. Figures $5 \mathrm{a}$ and $5 \mathrm{~b}$ present the influence of the polymer molecular weight as a function of $\mathrm{pH}$ and temperature for the response variable $K e$.

When analyzing the graph (Figure 5a), a similar behavior was verified to that observed for $K p$ (Figure 4a). This indicates that the ATPSs formed from PEG and potassium phosphate buffer are suitable for the separation of $\alpha$-amylase, since they promoted partitioning of this biomolecule without significant loss of biological activity.

Alcântara et al. (2013), studying the extraction and purification of amyloglucosidase with ATPSs formed by polyethylene glycol and sodium polyacrylate, noted that the partition coefficient of amyloglucosidase activity decreased when the $\mathrm{pH}$ was greater than 6.5 .

With regard to temperature, similar behavior to that observed in Figure 3 was observed, reinforcing that the ATPSs studied are suitable as a technique to preconcentrate the $\alpha$-amylase enzyme.

Bassani et al. (2010), when studying the interaction between a lipase from Candida rugosa in aqueous two-phase systems consisting of potassium phosphate and polyethylene glycol, verified by the fluorescence and circular dichroism approaches that the polymer does not affect the secondary and tertiary structure of this enzyme, nor its biological activity.

\section{Partition of $\alpha$-Amylase Produced by Solid State Fermentation (SSF)}

As shown in the partition study of pure $\alpha$-amylase, the molecular weight of the polymer was the variable that most influenced this enzyme separation process. Thus, a treatment was selected for each molecular weight used in the face-centered central composite design, with the aim of studying the partitioning behavior of the crude enzyme extract obtained in solid state fermentation. The selection was made by observing the best $\mathrm{Ke}$ and $\mathrm{Kp}$ values for each. Table 6 shows the results encountered for the variables Ke, Kp and $\mathrm{S}$ under these conditions.

Analyzing the data presented for the protein partition coefficient $(\mathrm{Kp})$ of 1.520 and enzymatic activity $(\mathrm{Ke})$ of 7.560 in Table 6 , it can be observed that the use of PEG 2000 strongly influenced the partition of the crude extract proteins to the upper phase. It was verified that $\alpha$-amylase has a greater affinity for that phase than the other proteins, since the value found for selectivity was greater than one (4.974). Porfiri et al. (2011) assessed the partitioning of $\alpha$-amylase from Aspergillus oryzae in PEG-phosphate systems and also noted that the enzyme has a greater affinity for the upper phase when employing polyethylene glycol with a molecular weight of 2000 .

With the increase in molecular weight of the polymer, which is rich in one phase, there occurred a decrease in partitioning of the crude enzyme extract to the same phase. Greater migration of $\alpha$-amylase to the lower layer was observed (salt-rich) than other proteins in the crude enzyme extract, where the 


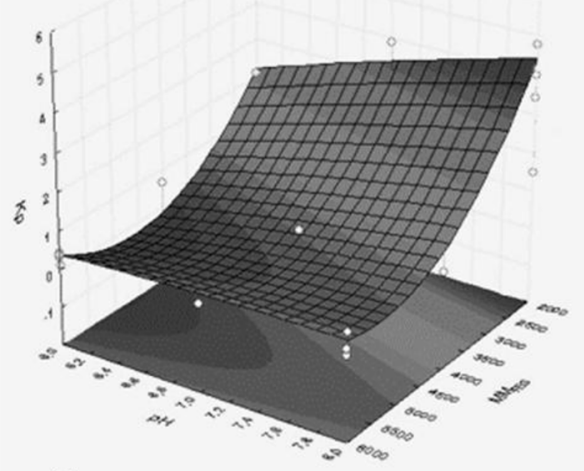

a

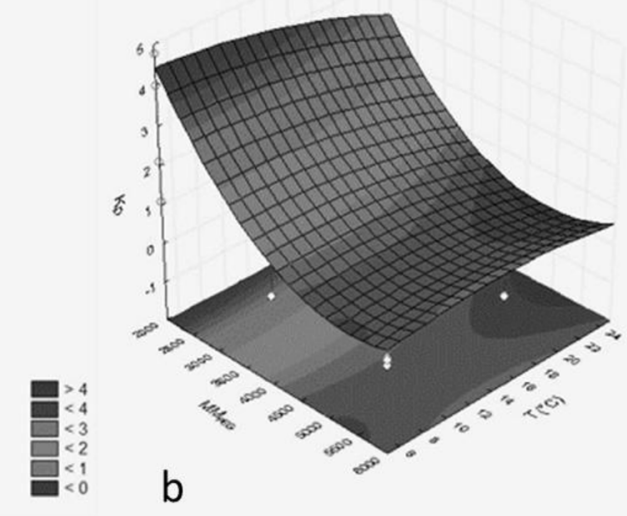

Figure 5. Response surface for the enzyme activity partition coefficient as a function of the molar mass of the polymer: a) (MMPEG) and $\mathrm{pH}$; b) (MMPEG) and $\mathrm{T}\left({ }^{\circ} \mathrm{C}\right)$.

selectivity values were significantly less than one. Naturally, this increase in the degree of polymerization of the polymer forming the ATPSs decreased the configurational entropy of the polymer-rich phase, reducing the transfer entropy value of the protein to this phase. Zuñiga et al. (2001) also found that increasing the molar mass of the polymer and increasing the concentration of $\alpha$-lactalbumin protein in the lower phase caused a decrease in the partition coefficient.

It is therefore evident that the ATPSs presented in this study may be an alternative for pre-concentration of $\alpha$-amylase, considering that this is a technique that uses low-cost materials and presents good selectivity for separation of this enzyme.

\section{CONCLUSIONS}

The results indicated that the optimum point for the production of $\alpha$-amylase from Aspergillus niger is 35 hours of fermentation and moisture of $45.7 \%$. As for the separation process, it was found that the increase in the polymer molecular weight promotes the reduction of the enzyme concentration in the top phase (rich in polymer), increasing its concentration in the bottom phase (high salt) and maintaining the biological activity of the enzyme in both phases. It was also observed that the partition coefficients increase with increasing values of $\mathrm{pH}$ and a temperature reduction. The partition time was significant only for the variable $\mathrm{Ke}$. As to the results found for $\alpha$-amylase partition from the FES, it was found that there was a good selectivity, indicating that this enzyme has a greater affinity for each phase under the conditions studied than the other proteins present in the crude enzyme extract.
Therefore, it is concluded that the analyzed aqueous two-phase systems present a good alternative for preconcentration of the $\alpha$-amylase enzyme.

\section{REFERENCES}

Alcântara, L.A.P., Amaral, I.V., Bonomo, R.C.F., da Silva, L.H.M., da Silva, M.d.C.H., Minim, V.P.R., Minim, L.A., Partitioning of $\alpha$-lactalbumin and $\beta$-lactoglobulin from cheese whey in aqueous twophase systems containing poly (ethylene glycol) and sodium polyacrylate. Food and Bioproducts Processing, 92, 409-415 (2014).

Bassani, G., Fuciños, P., Picó, G., Farruggia, B., Candida rugosa lipase Lip1-polyethyleneglycol interaction and the relation with its partition in aqueous two-phase systems. Colloids and Surfaces B: Biointerfaces, 75, 532-537 (2010).

Bhanja Dey, T., Banerjee, R., Purification, biochemical characterization and application of $\alpha$-amylase produced by Aspergillus oryzae IFO-30103. Biocatalysis and Agricultural Biotechnology, 4, 83-90 (2015).

Bradford, M.M., A rapid and sensitive method for the quantitation of microgram quantities of protein utilizing the principle of protein-dye binding. Analytical Biochemistry, 72, 248-254 (1976).

de Sousa, R.d.C.S., dos Reis Coimbra, J.S., da Silva, L.H.M., da Silva, M.d.C.H., Rojas, E.E.G., Vicente, A.A.A., Thermodynamic studies of partitioning behavior of lysozyme and conalbumin in aqueous two-phase systems. Journal of Chromatography B, 877, 2579-2584 (2009). 
de Souza Jr, E.C., Coimbra, J.S.R., de Oliveira, E.B., Bonomo, R.C.F., Recovery of caseinderived peptides with in vitro inhibitory activity of angiotensin converting enzyme (ACE) using aqueous two-phase systems. Journal of Chromatography B, 973, 84-88 (2014).

dosSantos, T.C., Gomes, D.P.P., Bonomo, R.C.F., Franco, M., Optimisation of solid state fermentation of potato peel for the production of cellulolytic enzymes. Food Chemistry, 133, 1299-1304 (2012).

Eliasson, A.-C., Carbohydrates in food. CRC Press (2006).

Francis, F., Sabu, A., Nampoothiri, K.M., Ramachandran, S., Ghosh, S., Szakacs, G., Pandey, A., Use of response surface methodology for optimizing process parameters for the production of $\alpha$-amylase by Aspergillus oryzae. Biochemical Engineering Journal, 15, 107-115 (2003).

Galembeck, F., Barbosa, C.A.S., Sousa, R.A.d., Aproveitamento sustentável de biomassa e de recursos naturais na inovação química. Química Nova, 32, 571-581 (2009).

Giraldo-Zuñiga, A.D., dos Reis Coimbra, J. S., Minim, L.A., Coeficientes de partição da $\alpha$-lactoalbumina e $\alpha$-lactoglobulina em sistemas aquosos bifásicos: influência da massa molar do polímero. Ciencia y Tecnología de México, 149-155 (2001).

Ghose, T., Measurement of cellulase activities. Pure and Applied Chemistry, 59, 257-268 (1987).

Gupta, R., Gigras, P., Mohapatra, H., Goswami, V.K., Chauhan, B., Microbial $\alpha$-amylases: a biotechnological perspective. Process Biochemistry, 38, 1599-1616 (2003).

Kunamneni, A., Singh, S., Response surface optimization of enzymatic hydrolysis of maize starch for higher glucose production. Biochemical Engineering Journal, 27, 179-190 (2005).

Mageste, A.B., Senra, T.D.A., da Silva, M.C.H., Bonomo, R.C.F., daSilva, L.H.M., Thermodynamics and optimization of norbixin transfer processes in aqueous biphasic systems formed by polymers and organic salts. Separation and Purification Technology, 98, 69-77 (2012).

Miller, G.L., Use of dinitrosalicylic acid reagent for determination of reducing sugar. Analytical Chemistry, 31, 426-428 (1959).

Okolo, B.N., Ezeogu, L.I., Mba, C.N., Production of raw starch digesting amylase by Aspergillus niger grown on native starch sources. Journal of the Science of Food and Agriculture, 69, 109-115 (1995).
Padilha, G.S., Ferreira, J.F., Castiglioni, G.L., Alegre, R.M., Tambourgi, E.B., Avaliação da lipase extracelular de Pseudomonas cepacia para purificação em sistema bifásico aquoso. Food Science and Technology (Campinas), 31, 16-22 (2011).

Pei, Y., Wang, J., Wu, K., Xuan, X., Lu, X., Ionic liquid-based aqueous two-phase extraction of selected proteins. Separation and Purification Technology, 64, 288-295 (2009).

Pelizer, L.H., Pontieri, M.H., Moraes, I.d.O., Utilização de Resíduos Agro-Industriais em Processos Biotecnológicos como Perspectiva de Redução do Impacto Ambiental. 2007 2, 10 (2007).

Pereira Alcântara, L.A., doNascimento, K.S., Mourão, C.A., Minim, V.P.R., Minim, L.A., Aqueous twophase poly(ethylene glycol)-sodium polyacrylate system for amyloglucosidase purification: Equilibrium diagrams and partitioning studies. Separation and Purification Technology, 118, 888894 (2013).

Pessoa, A., Kilikian, B., Purificação de produtos biotecnológicos. Manole (2005).

Peters, T.J., Partition of cell particles and macromolecules: Separation and purification of biomolecules, cell organelles, membranes and cells in aqueous polymer two phase systems and their use in biochemical analysis and biotechnology. P-A. Albertsson. Third Edition, 1986, John Wiley and Sons, Chichester, £61.35, pages 346 [book review]. Cell Biochemistry and Function, 5, 233234 (1987).

Porfiri, M.C., Picó, G., Romanini, D., Farruggia, B., Aspergillus oryzae alpha-amylase partition in potassium phosphate-polyethylene glycol aqueous two-phase systems. International Journal of Biological Macromolecules, 49, 7-13 (2011).

Porto, C.S., Porto, T.S., Nascimento, K.S., Teixeira, E.H., Cavada, B.S., Lima-Filho, J.L., Porto, A.L.F., Partition of lectin from Canavalia grandiflora Benth in aqueous two-phase systems using factorial design. Biochemical Engineering Journal, 53, 165171 (2011).

Rodriguez-Duran, L.V., Spelzini, D., Boeris, V., Aguilar, C.N., Pico, G.A., Partition in aqueous two-phase system: its application in downstream processing of tannase from Aspergillus niger. Colloids Surf B Biointerfaces, 101, 392-397 (2013).

Salabat, A., The influence of salts on the phase composition in aqueous two-phase systems: 
experiments and predictions. Fluid Phase Equilibria, 187-188, 489-498 (2001).

Saravanan, S., Rao, J.R., Nair, B.U., Ramasami, T., Aqueous two-phase poly(ethylene glycol)poly(acrylic acid) system for protein partitioning: Influence of molecular weight, $\mathrm{pH}$ and temperature. Process Biochemistry, 43, 905-911 (2008).

Singh, K., Kayastha, A.M., A-amylase from wheat (Triticum aestivum) seeds: its purification, biochemical attributes and active site studies. Food Chemistry, 162, 1-9 (2014).

Thomas, L., Larroche, C., Pandey, A., Current developments in solid-state fermentation. Biochemical Engineering Journal, 81, 146-161 (2013).
Tung, T.Q., Miyata, N., Iwahori, K., Growth of Aspergillus oryzae during treatment of cassava starch processing wastewater with high content of suspended solids. Journal of Bioscience and Bioengineering, 97, 329-335 (2004).

Whitaker, J.R., Principles of Enzymology for the Food Sciences, 2nd Edition. Taylor \& Francis (1993).

Zafarani-Moattar, M.T., Hamzehzadeh, S., Saltingout effect, preferential exclusion, and phase separation in aqueous solutions of chaotropic water-miscible ionic liquids and kosmotropic salts: Effects of temperature, anions, and cations. Journal of Chemical \& Engineering Data, 55, 1598-1610 (2010). 